Original Research Paper

\title{
Pelatihan Bahasa Pemograman Python Berbasis Modul Sympy Untuk Memvisualisasi Konsep Fisika Matematika Bagi Mahasiswa Calon Guru
}

\author{
Jannatin 'Ardhuha1*, I Wayan Sudiarta², Lalu Rudyat Telly Savalas ${ }^{3}$, Ap'aluddin', Thufail Mujaddid Al- \\ Qoyim $^{1}$, Putri Julia Maemum', Mega Safana', Ahmad Fadli', Nurjamilah', Muhamad Hendri Diarta ${ }^{1}$, \\ Chorina Ika Ristanti ${ }^{1}$, Nanda Nabila Maharani ${ }^{1}$, Siti Nurkhaliza ${ }^{1}$, Ulfa Dwiyanti ${ }^{1}$
}

${ }^{1}$ Program Studi Pendidikan Fisika, FKIP Universitas Mataram, Mataram, Indonesia

${ }^{2}$ Program Studi Fisika, FMIPA Universitas Mataram, Mataram, Indonesia

${ }^{3}$ Program Studi Pendidikan Kimia, FKIP Universitas Mataram, Mataram, Indonesia

https://doi.org/10.29303/jpmpi.v3i2.1238

Sitasi: Ardhuha, J., Sudiarta, I. W., Savalas, L. R., Ap’aluddin., Al-Qoyim, T. M., Mamun, P. J., Fadli, A., Nurjamilah., Diarta, M. H., Ristanti, C. I., Maharani, N. N., Nurkhaliza, S \& Dwiyanti, U. (2021). Pelatihan Bahasa Pemograman Python Berbasis Modul Sympy Untuk Memvisualisasi Konsep Fisika Matematika Bagi Mahasiswa Calon Guru. Jurnal Pengabdian Magister Pendidikan IPA 4(4)

Article history

Received: 19 Oktober 2921

Revised: 30 Oktober 2021

Accepted: 30 November 2021

*Corresponding Author:

Jannatin 'Ardhuha, Program Studi Pendidikan Fisika, FKIP Universitas Mataram, Mataram, Indonesia;

Email: j.ardhuha@unram.ac.id

\begin{abstract}
Basic programming skills are perceived to be increasingly important in this rapidly changing era. Mastery of programming languages is not only important for informatics and computer technology activists, but also becomes essential for science, science education, and pre-service science teachers. To deal with this matter, an outreach program has been carried out in by undertaking python language training with sympy module for prospective science teachers. The activity aims to give training to student teacher to have basic knowledge in python programming by using sympy module, to gain a deeper skill to visualize physical mathematics concepts and utilize the absorbed skills in mastering other physics concepts. The training includes introduction to python language, python-jupyter and sympy installation, script and module usage, introduction to google collab and application python-based sympy module to visualize concepts in physical mathematics. The two days training activities received good response from participants. A total of $95.5 \%$ of participants rated the training material as highly relevant and in line with expectations of participating in the training. In addition, the discussion and Q\&A activities at the end of the activity also help participants to understand the material better. Students particularly learnt to solve problems in physical mathematics easily and quickly when using python-based programs sympy module. From the series of activities that have been carried out, it can be concluded that this outreach activity showed an obvious benefit for science student teachers, and hence it is advisable to do similar activities with broader participants in the future.
\end{abstract}

Keywords: python program, sympy module, physical mathematics.

\section{Pendahuluan}

Fisika Matematika merupakan salah satu mata kuliah wajib bagi mahasiswa calon guru di Program Studi Pendidikan Fisika. Penguasaan konsep, prinsip, dan teori matematika dasar seperti limit, fungsi dan persamaan, dan integral turunan (Gesche, P., dkk, 2015; Bruce, L., S., 2001) merupakan syarat utama bagi mahasiswa jika ingin berhasil mencapai indikator dan kemampuan akhir pada kuliah ini. Hal ini mendorong, para pengajar (dosen) memberikan 
serangkaian contoh dan latihan soal dalam kegiatan perkuliahan, hal ini bertujuan untuk melatih mahasiswa dalam menganalisis, menemukan dan menyelesaikan masalah yang berhubungan dengan fenomena fisika sesuai dengan konsep, prinsip dan pendekatan matematis. Akan tetapi, mahasiswa sering kali menanggapi pemberian latihan soal ini sebagai sesuatu yang sulit untuk dikerjakan (Dewi, H., M., 2019; I Wayan G., dkk, 2017; Dwi F., S., dkk, 2016), membosan, tidak menyenangkan, membebankan mereka, tahu kapan akan dipergunakan dan terkadang terasa tidak menantang.

Apabila keadaan seperti ini dibiarkan dan dianggap dan angin lalu, maka akan berdampak bagi rendahnya ketercapaian kompetensi pembelajaran yang dimiliki mahasiswa pada mata kuliah ini, dan lebih lanjut akan berpengaruh pada profil lulusan Program Studi Pendidikan Fisika, serta kesiapan mereka dalam menghadapi kebutuhan dan tantangan abad 21. Inovasi pembelajaran merupakan salah satu hal yang perlu dilakukan, perlu kreativitas dosen dalam meramu pembelajaran dalam kegiatan perkuliahan dari sesuatu yang tidak disukai dan dihindari, menjadi sesuatu yang menyenangkan, menantang, bermakna serta berguna bagi mahasiswa di kehidupan masa mendatang.

Untuk mengetahui pendapat mahasiswa mengenai kuliah Fisika Matematika yang dilaksanakan oleh Program Studi Pendidikan Fisika FKIP Universitas Mataram, maka dilakukan survei menggunakan angket yang disebar kepada mahasiswa secara online. Sebanyak 65 dari 68 responden menyatakan bahwa Fisika Matematika merupakan kuliah yang sulit. Mereka merasa kesulitan dalam memahami, menghapal, dan menjabarkan rumus, sulit menjawab soal, belum menguasai Matematika Dasar, kurang memahami konsep yang diajarkan dalam kuliah ini, sulit memahami buku teks berbahasa Inggris, serta pelaksanakan perkuliahan di masa pandemi ini diselenggarakan secara online, maka mahasiswa merasa makin sulit menguasai materi kuliah ini.
Mahasiswa berpendapat pemberian visualisasi dalam penyajian materi Fisika Matematika berupa penggunaan animasi, simulasi atau bahasa pemogram, yang merupakan kolaborasi teknologi, media pembelajaran dan penjelasan dosen dapat menjadi salah satu solusi untuk mengatasi kesulitan yang mereka alami tersebut. Akan tetapi, sebagian besar dari responden belum memiliki pengetahuan dan keterampilan mengenai bahasa pemrograman, terutama program Python. Hal inilah yang menyebabkan $88,2 \%$ responden tertarik untuk belajar bahasa pemograman tersebut. Seluruh responden menyambut baik dan bersemangat jika diadakan pelatihan penggunaan bahasa pemrograman yang dapat memberikan visualisasi (gambaran) mengenai konsep yang diajarkan di mata kuliah Fisika Matematika.

Penyelenggaraan pelatihan python secara online makin marak ditawarkan oleh lembaga-lembaga kursus, universitas, lembaga pemerintahan dan pihak lainnya baik itu yang berbayar atau pun gratis. Trend ini sejalan dengan karakteristik bahasa pemrograman python yang sederhana dan praktis tetapi multifungsi. Berdasarkan pemeringkatan yang dilakukan oleh Tiobe pada bulan November 2021, bahasa pemogram python menempati urutan pertama sebagai bahasa pemograman yang popular dan paling banyak dicari mesin pencarian.

Python merupakan bahasa pemrograman tingkat tinggi yang digagas oleh Guido van Rossum (Kalyani, A., 2017). Mengapa bahasa python sangat popular? Jawabannya, karena python merupakan bahasa pemrograman yang sederhana, mudah dipelajari dan dipahami oleh para pemula jika dibandingkan dengan bahasa pemrograman lain seperti bahasa $\mathrm{C}$ dan $\mathrm{C}++$ (Jacco, H., 2012; Kalyani, A., 2017). Kode bahasa Python berupa script, perintah-perintah atau pernyataan-pernyataan yang tidak memerlukan kompilasi sehingga bisa langsung dijalankan (I Wayan S., 2019). Salah satu modul yang ditawarkan dalam program python adalah modul sympy, di mana modul ini menyediakan 
fasilitas operasi matematik simbolik, yang dapat dipergunakan untuk menyelesaikan perhitungan matematis seperti matriks, turunan, integral dan lain sebagainya.

Berdasarkan pemaparan kesulitan mahasiswa di atas dan untuk menunjang ketercapaian kompetensi lulusan, maka perlu diadakan pelatihan yang bertujuan membuka wawasan dan melatih keterampilan mahasiswa calon guru dalam menyelesaikan persoalan fisika melalui penggunaan bahasa pemograman Pyhton berbasis modul sympy.

\section{Metode}

Untuk mencapai tujuan kegiatan pengabdian masyarakat ini, tim pengusul telah melaksanakan serangkaian kegiatan yaitu:

\section{Penyusunan modul pelatihan}

Untuk memudahkan pelaksanaan kegiatan ini, maka diperlukan modul pelatihan untuk memudahkan peserta dalam mengikuti setiap langkah-langkah yang dijelaskan oleh tutor (pemateri). Susunan materi dalam modul pelatihan berisi pengenalan pyhton, install program python-jupiter-sympy, pengenalan google colaboratory (colab) dan aplikasi pyhton berbasis modul sympy untuk visualisasi konsep Fisika Matematika.

\section{Promosi kegiatan pelatihan}

Untuk dapat menarik banyak peserta dalam pelatihan ini, maka tim pengusul, tim mahasiswa dan mitra melakukan promosi berupa penyebaran informasi mengenai kegiatan ini melalui media sosial dalam bentuk flyer, seperti ditunjukkan pada Gambar 1.

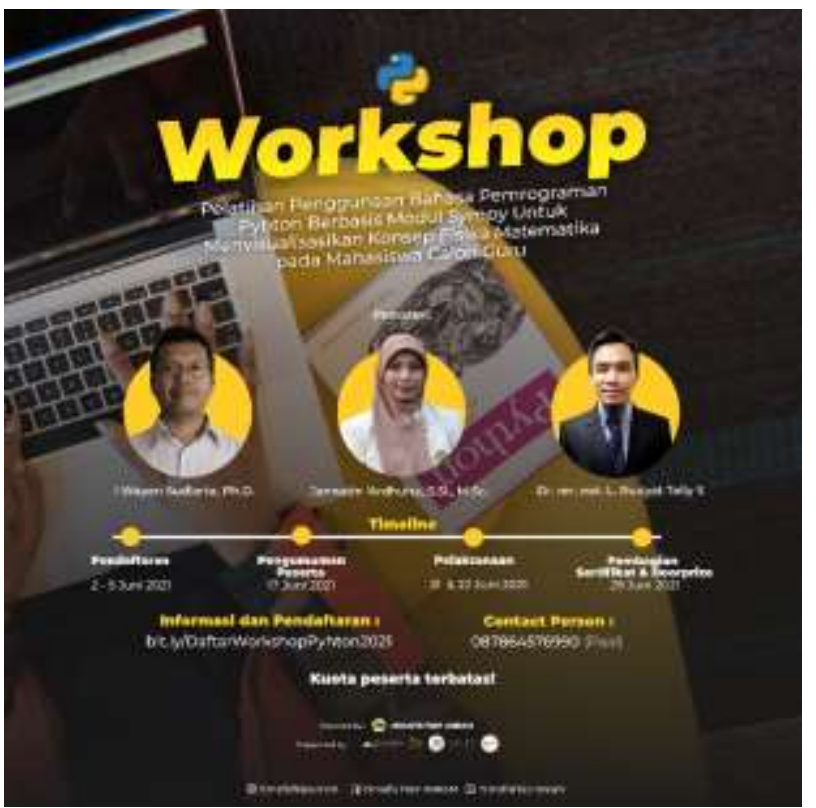

Gambar 1. Flyer workshop pelatihan penggunaan bahasa pemograman python berbasis modul sympy 2021.

3. Pelaksanaan pelatihan

Pelatihan dilaksanakan secara online melalui media zoom pada tanggal 21 dan 22 Juni 2021. Pelaksanaan pengabdian di hari pertama meliputi kegiatan-kegiatan sebagai berikut:

a. Pembukaan, terdiri dari sambutan dari ketua HIMAFIS dan ketua Program Studi Pendidikan Fisika FKIP Universitas Mataram.

b. Sosialisasi acara secara umum.

c. Penyampaian materi meliputi: "Kenapa Kuliah Fisika Matematika Sulit?; Python, Apakah Kita Butuh?; dan Berkenalan dengan Python".

d. Demonstrasi cara menginstal program python-jupiter-sympy pada OS Windows.

e. Tanya jawab untuk memberi kesempatan kepada peserta bertanya terkait dengan penyampaian materi dan penginstalan program, melalui kolom chat dan raise hand yang tersedia di zoom meeting, atau mengirim pesan di what's up group (WAG).

f. Kuis siapa cepat, kuis ini berupa pertanyaan-pertanyaan singkat seputar materi yang telah disampaikan, yang 
diajukan oleh pemateri atau panitia kepada peserta melalui aplikasi Socrative, bagi peserta yang cepat dan benar menjawab pertanyaan tersebut berhak mendapatkan door prize dari sponsor.

Urutan kegiatan workshop pada hari kedua ini hampir sama dengan hari pertama, meliputi pembukaan, penyampaian materi berupa: "La tahzan, Colab solusinya; Visualisation des données en python; dan Tschüss, schwierige Rechnung", demonstrasi cara menggunakan google colab, tanya jawab, kuis, serta pengumuman pemenang door prize.

4. Evaluasi kegiatan pelatihan.

Untuk mengetahui tingkat kepuasan dan keberhasilan dari pelatihan yang akan dilakukan, maka peserta pelatihan diminta mengisi angket evaluasi tersebut. Sehingga dari saran, masukan, dan kritik, maka akan ada bahan pertimbangan untuk perbaikan pada pelaksanaan pelatihan di masa yang akan datang.

\section{Hasil dan Pembahasan}

Kegiatan pengabdian masyarakat berupa workshop pelatihan bahasa pemograman python berbasis modul symsy untuk memvisualisasikan konsep Fisika Matematika telah dilakukan secara online pada tanggal 21 dan 22 Juni 2021, dan telah berlangsung dengan baik. Pelatihan ini diikuti oleh 78 peserta yang terdiri mahasiswa calon guru, mahasiswa sains (MIPA dan teknik), mahasiswa non sains (tata boga), dosen dan alumni yang berasal dari berbagai perguruan tinggi di Indonesia, seperti Universitas Mataram, ITS, ITB, Universitas Negeri Malang, Universitas Negeri Jakarta, Universitas Islam Indonesia, Universitas Andalas, Universitas Negeri Makassar, IAIN Salatiga, dan Universitas Muhammadiyah Mataram, serta guru dari SMKN 26 Jakarta dan MAN 2 Mataram. Narasumber dalam pengabdian ini adalah Jannatin 'Ardhuha, S.Si., M.Sc., I Wayan
Sudiarta, Ph.D., dan Dr. rer. nat. Lalu Rudyat Telly Savalas, M.Si.

Python merupakan bahasa pemograman yang dilatihkan dalam workshop ini. Untuk dapat menjalankan program ini, peserta pelatihan harus mengunduh dan menginstal program python, Jupiter dan sympy. Sebelum lakukan pengunduhan program python (baik versi 3.6.8 atau 3.9.5), peserta harus mengetahui versi Windows yang dipergunakan pada laptop atau komputernya. Demonstasi cara menginstal dan contoh bagaimana penulisan sintaks bahasa pemograman dalam menjalankan program python sebagai kalkulator dilakukan oleh I Wayan Sudiarta, Ph.D.

Materi pelatihan yang dikemas dalam bentuk file modul pelatihan telah diberikan ke peserta sebelum kegiatan pengabdian ini dimula. Hal ini bertujuan agar peserta dapat mempelajari terlebih dahulu materi pelatihan sebelum hari pelaksanaan kegiatan. Sehingga jika ada kesulitan yang dihadapi dalam memahami modul tersebut, dapat ditanyakan kepada narasumber pada saat workshop berlangsung.

Peserta yang mengalami kesulitan dalam mengunduh, menginstal dan menjalankan program diberikan kesempatan bertanya kepada narasumber pada saat sesi tanya jawab. Sebagai contoh, ada peserta yang yang tidak dapat menjalankan program python ketika menggunakan MacBook. Solusi yang diberikan adalah peserta dapat mengunduh program di https://www.python.org/downloads/macos/.

Selain melalui Windows dan Mac, program python dapat juga dioperasikan pada sistem linux dan Sun OC (Jacco, H., 2012).

Untuk mencairkan suasana dalam pelatihan ini, maka tim pengabdian mengadakan kuis siapa cepat dia dapat. Kuis ini dipandu oleh Dr. rer. nat. Telly Savalas, menyajikan pertanyaan secara online melalui aplikasi Socrative. Peserta yang benar dan paling cepat menjawab menjadi pemenang door prize yang disediakan oleh sponsor. Peserta hanya berkesempatan sekali menjadi pemenang tiap hari pelaksanaan. Sebagai contoh 
Habiburrahman, peserta yang asal Lamongan, yang merupakan mahasiswa Program Studi Matematika ITB berhasil menjadi pemenang pada kuis 1. Karena berhasil menjawab pertanyaan dengan benar, meskipun dia bukan yang tercepat dalam memberikan jawaban. Pengumuman seluruh pemenang door prize disampaikan pada hari akhir pelatihan.
Animo peserta untuk mengikuti kegiatan ini sangat tinggi, hal ini terlihat dari banyaknya jumlah peserta yang hadir yang dalam sesi foto bersama menjadi acara terakhir dari kegiatan pelatihan di hari pertama ini, seperti ditunjukan pada Gambar 2 berikut.
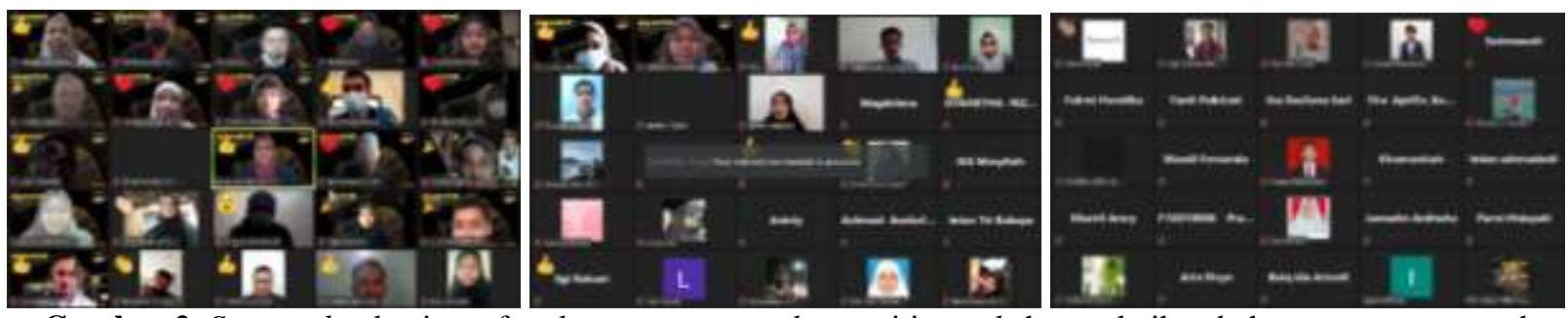

Gambar 2. Screen shot kegiatan foto bersama peserta dan panitia workshop pelatihan bahasa pemograman phyton berbasis modul sympy 2021.

Kegiatan pelatihan di hari kedua, narasumber menyajikan materi "La tahzan, Colab solusinya; Visualisation des données en python; dan Tschüss, schwierige Rechnung". Peserta yang kesulitan dalam mengunduh, menginstal dan menjalankan program pytonjupiter-sympy di laptop pada hari pertama, dapat menggunakan aplikasi google Colaboratory atau disingkat colab, (https://colab.research.google.com/ ). Aplikasi ini dapat dipergunakan sebagai sarana untuk berkolaborasi dalam membuat proyek melalui media komputasi awan (cloud computation). Penggunaan Colab ini didemonstrasikan oleh Jannatin 'Ardhuha, S.Si., M.Sc.

Tahapan terakhir dalam kegiatan pengabdian masyarakat ini adalah evaluasi pelaksanaan pelatihan python 2021. Tim pengabdian menggunakan instrumen angket yang disebar melalui formulir online (gform) kepada seluruh peserta pelatihan, tercatat ada 67 peserta (responden) yang mengisi angket tersebut. 60 responden menyatakan bahwa mereka mempersiapkan diri sebelum mengikuti pelatihan dengan cara menyiapkan kuota internet, membaca modul pelatihan, mengunduh dan menginstal aplikasi python-jupiter-sympy, mencoba beberapa langkah penggunaan bahasa pemograman python yang ada di modul, mempelajari video pengenalan python yang ada di youtube, dan mencari informasi tambahan mengenai python di google.

$74,6 \%$ responden berhasil mengunduh dan menginstal program yang dipergunakan dalam pelatihan ini. Sebanyak 40,3\% atau 27 responden menyatakan mereka mengalami kesulitan dalam menginstal program python. Kesulitan dijumpai dalam langkah penginstalan, laptop yang digunakan tidak berbasis OS windows, versi python yang diunduh tidak sesuai dengan spesifikasi laptop, belum pernah menginstal melalui cmd dan proses penginstalan berlangsung lama, dan program tidak dapat terinstal.

Tim pengabdian juga melakukan survei mengenai penyampaian materi oleh ketiga narasumber selama pelatihan berlangsung. Kriteria penilaian menggunakan skala Likert dari 5 (sangat baik), 4 (baik), 3 (cukup baik), 2 (kurang baik) dan 1 (sangat tidak baik). Lebih dari $50 \%$ responden menyatakan bahwa penyampaian materi disampaikan dengan sangat baik oleh para narasumber. 26,7 - 38,8 \% responden menyatakan baik dan kurang dari $11 \%$ menyatakan cukup baik. Sebaran nilai untuk tiap narasumber dapat dilihat pada Gambar 3. 


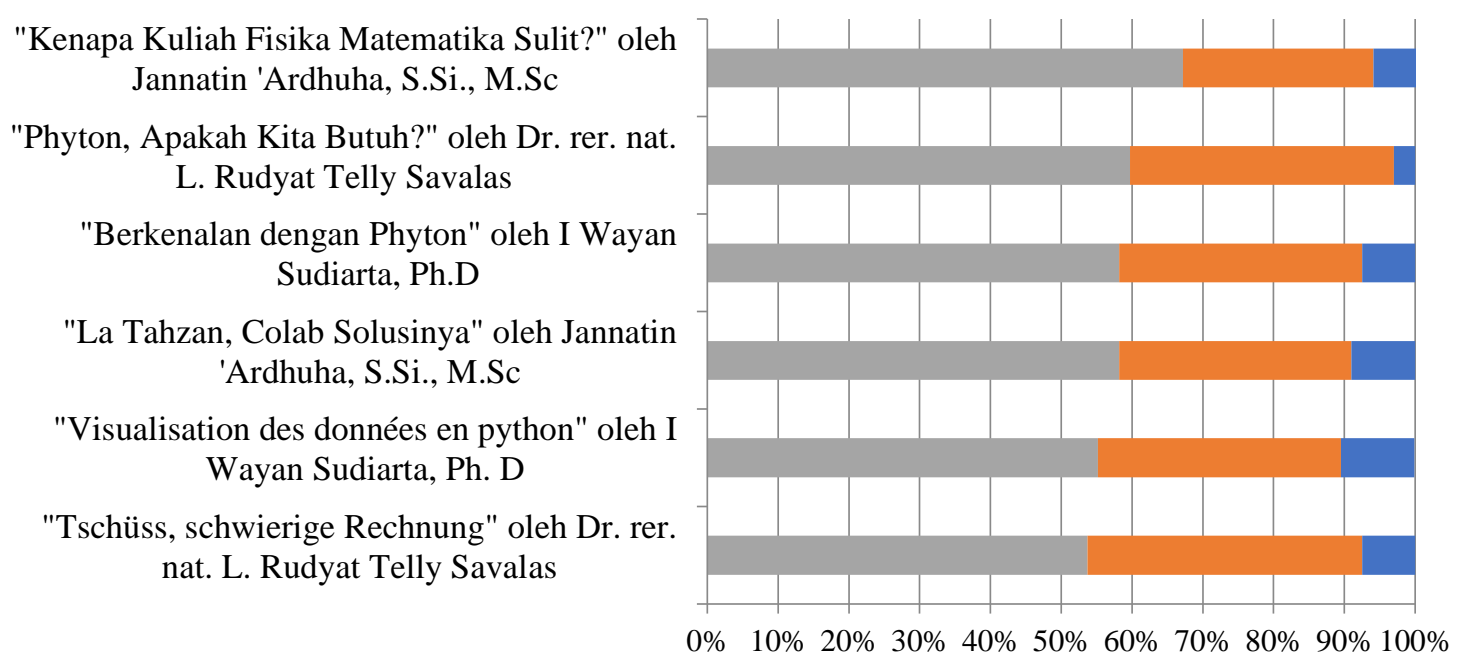

$\square$ Sangat Baik $₫$ Baik $₫$ Cukup Baik $₫$ Kurang Baik $₫$ Sangat Tidak Baik

Gambar 3. Penilaian responden terhadap penyampaian materi oleh narasumber.

Setelah mengikuti pelatihan ini, sebanyak 62 responden $(92,5 \%)$ menjawab mereka mendapatkan keterampilan baru seperti keterampilan dan pengetahuan dasar mengenai python, dapat menggunakan python dalam menyelesaikan determinan matriks dengan mudah, dapat menghitung dengan cepat dan benar, algoritma pemrograman phyton-jupiter, dapat mengoperasikan colab.research.google.com. Serta mereka dapat mengilustrasikan rumus fisika dan matematika dalam pemrograman python, membuat simbol, grafik (2D dan 3D) dan persamaan matematik menggunakan coding, dalam menyelesaikan permasalahanpermasalahan terkait penyelesaian matematika. Selain itu, 57 responden dapat mengoperasikan program Python yang diajarkan, walaupun terkadang mereka menemukan kesulitan pula. Kesulitannya dapat berupa penulisan/sintaks bahasa pemograman dan coding, membuat grafik multicolor, dan belum hapal kode/simbol.

Mayoritas responden merasa bahwa penggunaan bahasa pemrogranan Python berbasis modul sympy ini merupakan alternatif terbaik dalam memvisualisasikan konsep fisika matematika. Salah satu alasannya, karena bahasa pemograman metode sympy hampir sama dengan penulisan matematik biasa, sehingga mudah untuk dipelajari dan digunakan untuk tujuan tersebut. Ada pula peserta yang menuliskan bahwa penggunaan library Matplotlib sebagai solusi terbaik dalam visualisasi karena lebih popular, dengan modul tutorialnya yang lebih lengkap dan tersedia forum diskusinya lebih luas di internet.

Responden menyarankan agar pemaparan materi mengenai dasar-dasar python disampaikan terlebih dahulu, penjelasan dalam menginstal program dilakukan lebih pelan, waktu pelatihan lebih lama, dan dapat dilaksanakan secara luring, serta acara dimulai tepat waktu. Kesan positif dari peserta seperti pelatihan ini sangat bagus, bermanfaat, serta gratis, sangat menyenangkan dan menginspirasi, menambah wawasan dan diharapkan ada kelanjutan pelatihan berupa pendalaman materi dan pemaparan fungsi lain dari python, serta dapat disosialisasikan di sekolah.

98,5\% responden tertarik untuk mengikuti acara Workshop yang akan selenggarakan oleh tim pengabdian di lain waktu dengan tema/topik berbeda. Topik yang diinginkan berupa lanjutan workshop python; 
aplikasi lain python untuk memvisualisasikan materi fisika kuantum, kimia, statistika dasar, mekanika, fisika modern, metode numerik; pembuatan simulasi; bahasa pemograman lain seperti C++ dan java script; Library matlplotib.pyplot untuk visualisasi data; psikologi remaja; revolusi finansial; desain grafis, R studio; pengembangan diri; dan lain sebagainya. Ringkasan dari respon peserta terhadap pelaksanaan workshop python ini dapat dilihat pada Gambar 4 berikut ini.

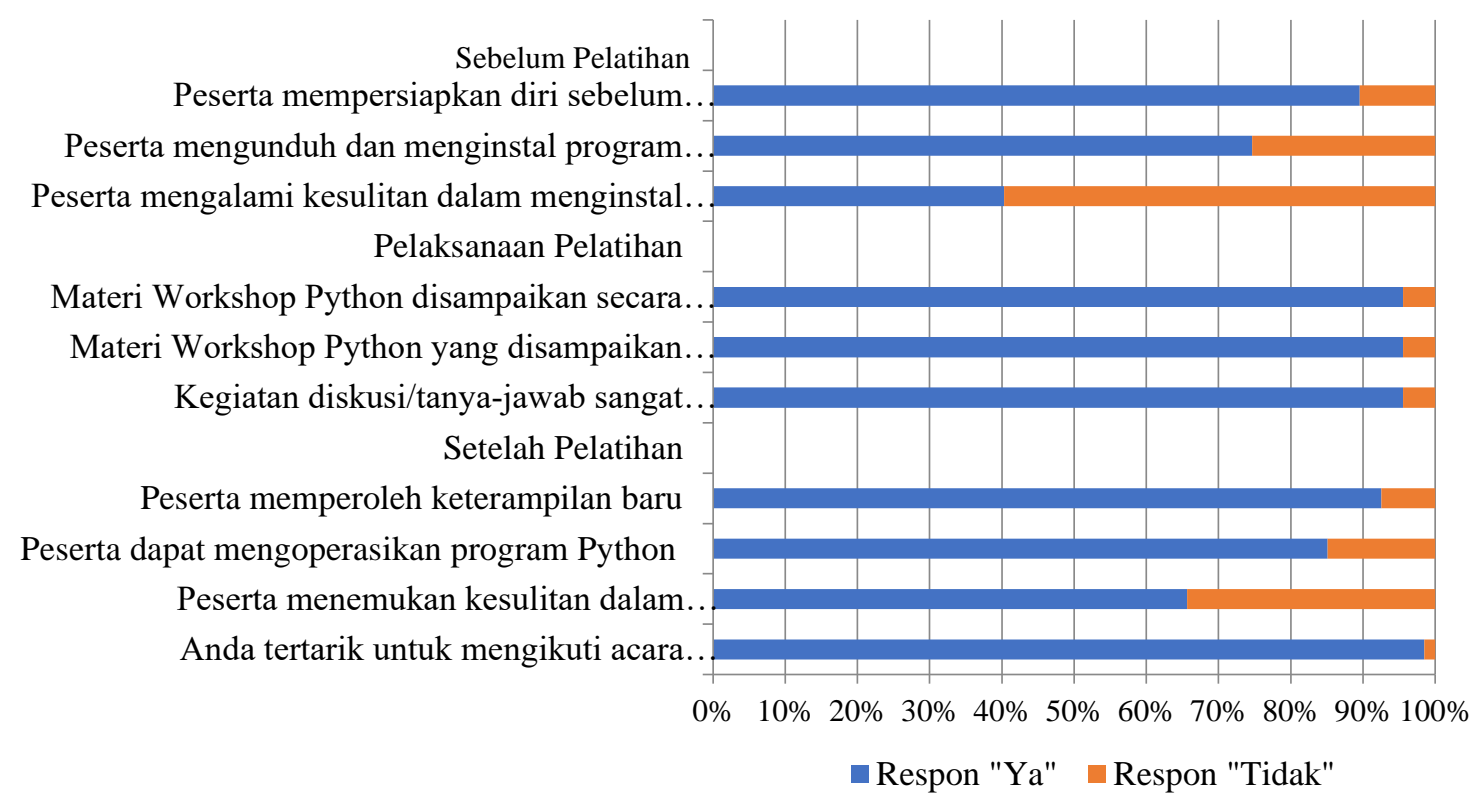

Gambar 4. Respon peserta sebelum, saat pelaksanaan dan setelah pelatihan python 2021.

Kesalahan dalam menulis sintaks bahasa pemograman python seperti kurang tanda kutip, tanda kurung, titik dua, salah menulis huruf kapital atau huruf kecil, terkadang membuat frustasi mahasiswa ketika mengetik kode, hal ini menyebabkan perintah tidak dapat dijalankan oleh komputer, (Andrew A., D., 2021). Fenomena ini dapat dipandang sebagai sesuatu yang wajar, karena sebagian besar peserta pelatihan merupakan pengguna pemula program python. Sehingga mereka merasakan bahasa pemograman bukanlah pembelajaran yang mudah untuk dipelajari karena berkenaan dengan konsep yang abstrak dan kurang pahamnya mahasiswa dalam memahami instruksi dalam pemrograman, (Essi, L., Kirsti A., Hannu-Matti J., 2005).

Peserta pelatihan diajurkan untuk membaca kembali modul pelatihan yang diberikan, melakukan latihan dan praktek yang intensif dalam menggunakan bahasa pemograman python berbasis modul sympy dan melakukan self-evalution jika ada kesalahan dalam menuliskan program. Berdasarkan hasil pemaparan di atas, dapat dikatakan bahwa pelaksanaan pelatihan bahasa pemograman python ini mencapai tujuan dan sasaran yang telah ditetapkan.

\section{Kesimpulan}

Kegiatan pengabdian kepada masyarakat ini dirasakan secara nyata manfaatnya oleh mahasiswa calon guru, sehingga di masa mendatang kegiatan serupa dapat dikembangkan dengan materi yang lebih kaya dan bersifat multidisiplin. Untuk dapat menfasilitasi mahasiswa belajar bahasa pemograman ini secara mandiri, aktif, dan menyenangkan, maka pada kegiatan selanjutnya dapat dikembangkan modul pelatihan yang inovatif dan sistem manajemen pembelajaran (LMS) yang dapat diakses oleh peserta pelatihan. 


\section{Ucapan Terima Kasih}

Penulis mengucapkan terima kasih kepada HIMAFIS Pendidikan Fisika FKIP Universitas Mataram selaku mitra dan Devy Indasari (My Sissy), Malahayati Rahayu Sulastri (Taliwang $\mathrm{Bu}$ Djafis), Mulya Rahmawati (Mulya Daily Hijab), Tiara Kusuma Cahya (Juji Flowers), Mega Safana (Hello Art), Nurjamilah (Berajah Solution) selaku sponsor doorprize pada kegiatan pengabdian kepada masyarakat ini.

\section{Daftar Pustaka}

Andrew A., D., 2021. Introducing Python Programming into Undergraduate Biology. The American Biology Teacher, Vol. 83, Issue 1, hal. 33-41.

Bruce, L., S., 2001. How Students Understand Physics Equations. Cognitive Instruction, Vol. 19, Issue 4, hal. 479541.

Dewi, H., M., 2019. The Effect of Task-Based Collaborative Learning on Students' Mathematical Physics Learning Outcomes at Universitas Muhammadiyah Makassar. Jurnal Pendidikan Fisika, Vol. 7, No.2, hal. 140-150.

Dwi F., S., Syarifah F., dan Wahyudi, 2016. Efektivitas Penggunaan Buku Ajar Fisika Matematika Berbasis Inkuiri dalam Perkuliahan Fisika Matematika. Jurnal Penelitian \& Pengembangan Pendidikan Fisika, Vol. 2 No. 2, hal. 713, Desember 2016.

Essi, L., Kirsti A., Hannu-Matti J., 2005. A Study of The Difficulties of Novice Programmers. Proceeding Proceedings of the 10th Annual SIGCSE Conference on Innovation and Technology in Computer Science Education (ITiCSE '05), June 2005, hal. 14-18. Caparica Portugal 27 - 29 Juni 2005.
Gesche, P., BatSheva, E., Esther, B., Yaron, L., dan Marie-Annette, G., 2015. The role of Mathematics for Physics Teaching and Understanding. Il Nuovo Cimento, Vol. 38, Issue 3, May-June, hal. 1- 10.

I Wayan, G., Joni, R., Hikmawati, dan Kesipudin, 2017. Pengembangan Bahan Ajar Kompilasi Fisika Matematika II Pokok Bahasan Persamaaan Diferensial Untuk Meningkatkan Penalaran Fisika. Jurnal Pendidikan Fisika dan Teknologi, Vol. 3 No.2, Desember 2017.

I Wayan, S., 2019. Metode Numerik. Edisi pertama, Arga Puji Press, Mataram.

Jacco, H., 2012. Goodbye Matlab! Hello Python!; Changing the Programming Language in Our Curriculum. Leonardo Times, 16 (June) 2012, hal. 24-25. Society for Aerospace Engineering Students VSV Leonardo da Vinci.

Kalyani, A., 2017. Python ProgrammingApplications and Future. International Journal of Advance Engineering and Research Development, Special Issue SIEICON-2017, Vol. 4, Issue 04, hal. 14, April 2017. 